\title{
BIBLIOTEKA STOWARZYSZENIA WZAJEMNEJ POMOCY PRACOWNIKÓW HANDLOWYCH W ŁODZI W LATACH 1887-1918
}

Biblioteka Stowarzyszenia Wzajemnej Pomocy Pracowników Handlowych, licząca w 1918 roku ok. 10 tys. woluminów, była na przełomie wieków jednym z większych i zasobniejszych księgozbiorów na terenie Łodzi. Wiele informacji o jej organizacji i rozwoju dostarczają drukowane corocznie sprawozdania Stowarzyszenia. Szczegółową analizę zawartości zbiorów umoźliwia opublikowany w 1903 r. katalog biblioteki. Dopełniają ten materiał liczne wzmianki o działalności Stowarzyszenia rozsiane w prasie lokalnej, a także w czasopismach warszawskich ${ }^{1}$.

Pomimo stosunkowo bogatej bazy źródłowej i prężnej - jak na łódzkie warunki - działalności, biblioteka Stowarzyszenia Handlowców nie doczekała się dotychczas żadnego monograficznego opracowania swych dziejów ${ }^{2}$. Zasługuje zaś na nie z pewnościa, jako jedna z nielicznych w „złym mieście”3 placówek bibliotecznych systematycznie rozwijających się i poszerzających zasięg oddziaływania na przestrzeni trzydziestu trudnych lat.

Stowarzyszenie Wzajemnej Pomocy Subiektów Handlowych, bo taką nazwę nosila początkowo ta organizacja, zostało utworzone w końcu $1886 \mathrm{r}$. ${ }^{4}$ i było jednym z pierwszych na terenie Łodzi związków skupiających przedstawicieli określonej grupy zawodowej. Wzorem dla łodzian była najprawdopodobniej organizacja analogicznej korporacji utworzona w roku 1884 w Warszawie pod nazwą Stowarzyszenie Wzajemnej Pomocy Subiektów Handlowych i Przemysłowych m. Warszawy. Zrzeszało ono przede wszystkim subiektów wyznań chrześcijańskich, w przeciwieństwie do istniejącego już od 1856 r. Stowarzyszenia Wzajemnej Pomocy Subiektów Wyznania Mojżeszowego ${ }^{5}$.

Łódzkie Stowarzyszenie Subiektów nie zakładało żadnych ograniczeń wyznaniowych wobec przyjmowanych członków. Inicjatywa założycielska wyszła jednak ze środowiska żydowskiego i stąd członkami byli głównie przedstawiciele tej narodowości. Subiekci chrześcijańscy próbowali bojkotować akcję organizacyjną. W efekcie do Stowarzyszenia należało ich początkowo 50 przy liczbie Żydów - 250 . Nawet tak niewielka grupka chrześcijan nie była jednak w stanie należycie się skonsolidować w pierwszych wyborach zarządu, które przyniosły zdecydowany sukces środowisku żydowskiemu ${ }^{6}$.

Ludność żydowska stanowiła w latach dziewięćdziesiątych ubiegłego wieku blisko $30 \%$ ogółu mieszkańców Łodzi (Polacy - 46,4\%, a Niemcy $21,4 \%$ ) i była wewnętrznie ogromnie zróżnicowana'. Obok burżuazji żydowskiej, ciążącej wyraźrlie ku środowiskom niemieckim, obok proletariatu pozostającego często pod 
wpływem chasydyzmu, istniały grupy, zwłaszcza młodej inteligencji żydowskiej, które podlegały wyraźnym procesom asymilacyjnym. Autor monografii o Łodzi z początków XX w. określa ich jako „inteligencję polską wyznania mojżeszowego"i podkreśla ich czynny udział w życiu społecznym miasta ${ }^{8}$. Przedstawiciele tej grupy Żydów znaleźli się również w Stowarzyszeniu Wzajemnej Pomocy Subiektów Handlowych i wywierali znaczący wpływ na kierunki działalności związku.

Subiekci łódzcy zakładając własną organizację stawiali sobie za cel wszelką działalność samopomocową jak udzielanie pożyczek, zapomóg, pośredniczenie w obsadzaniu miejsc pracy. Oprócz zamierzeń solidarystycznych ważnym elementem w działalności Stowarzyszenia miało być rozwijanie kontaktów towarzyskich oraz zakładanie i utrzymywanie instytucji o charakterze oświatowo-kulturalnym.

Faktyczna realizacja zatwierdzonego w statucie prawa do własnej biblioteki wymagala jednak odrębnego zezwolenia władz gubernialnych. Zarząd Stowarzyszenia wystąpił więc ze stosowną petycją i oto w końcu grudnia 1887 roku gubernator piotrkowski przesłał na ręce policmajstra łódzkiego oczekiwane zezwolenie. Odpowiedzialność za funkcjonowanie biblioteki przyją na siebie przewodniczący Zarządu, a prawo korzystania ze zbiorów mieli jedynie członkowie. Gubernator zlecił policmajstrowi permanentne śledzenie działalności biblioteki ${ }^{9}$.

Fakt powołania do życia nowej placówki bibliotecznej został z uznaniem odnotowany przez jedyny wówczas polski organ prasowy w Łodzi - „Dziennik Łódzki"10. Poparcie jakiego, również w późniejszym okresie, udzielała ta gazeta bibliotece, jest tym bardziej zrozumiałe, że Łódź, miasto już wówczas blisko trzystutysięczne, posiadała zaledwie kilka placówek udostępniających książki. Ogólnodostępnych (choć oczywiście odpłatnie) było 5 wypożyczalni przy księgarniach i jedna samoistna. Charakter zamknięty miały zaś, zapoczątkowane również w 1887 r., biblioteki Towarzystwa Lekarskiego i Zakładów Akcyjnych K. Scheiblera ${ }^{11}$.

Znamienne jest, że niemal wszystkie te placówki założone zostały po roku 1880. Bowiem dopiero w latach osiemdziesiątych poczęło organizować się polskie życie kulturalne w Łodzi. Od 1884 r. ukazywał się wspomniany „Dziennik Łódzki”, w tym roku wydano też pierwszą polską książkę, a od 1888 r. funkcjonował stały teatr. Zaznaczyć trzeba, że tworzenie polskich wartości kulturalnych dokonywało się wówczas $w$ ciągłym ścieraniu z dominującym środowiskiem niemieckim. Wykształcenie się zaś rodzimej elity intelektualnej w mieście, którego gwałtowny rozwój przemysłowy wyznaczał „zapotrzebowanie” przede wszystkim na proletariat, było niezmiernie trudne.

W tej sytuacji organizacja jakiejkolwiek biblioteki z polskim księgozbiorem, nie była przedsięwzięciem łatwym, ani prostym. Łódzcy subiekci handlowi zaczęli, podobnie jak inne organizacje w tamtej epoce, od odwołania się do ofiarności publicznej. „Dziennik Łódzki” informował więc gdzie i na czyje ręce „... wiele osób... odczuwających umyslowe i moralne potrzeby ludzkie, a tem samem umiejących ocenić donioste znaczenie biblioteki pry omówionym Stowarzyszeniu..." może składać książki tak beletrystyczne jak i naukowe ${ }^{12}$. Przychylnie potraktowały prośbę Zarządu redakcje niektórych warszawskich czasopism i obiecały uwzględnić bonifikatę $w$ prenumeracie na rzecz czytelni Stowarzyszenia ${ }^{13}$. Niezależnie od oczekiwanych skłonności filantropijnych społeczeństwa Zarząd Stowarzyszenia w 
budżecie na rok 1888 przeznaczył już sumę 300 rubli na gazety i książki. Stanowiło to nieco ponad $8 \%$ wszystkich planowanych na ten rok wydatków ${ }^{14}$.

Przygotowania do otwarcia biblioteki i czytelni trwały kilka miesięcy. Dopiero we wrześniu 1888 r., po zapoznaniu się z regulaminem czytelni Warszawskiego Towarzystwa Subiektów i po znalezieniu odpowiedniego lokalu, w którym wyznaczono też miejsce dla czytelni i biblioteki, Stowarzyszenie udostępniło swym członkom zgromadzone zbiory ${ }^{15}$. Zbiory te liczyły kilkaset tomów książek, a czytelnia oferowała około 20 tytułów czasopism.

Podobnego typu akcje tworzenia wlasnych bibliotek miały miejsce również w innych stowarzyszeniach powstających w latach dziewięćdziesiątych (i później) na terenie Łodzi. Podstawowy trzon zbiorów stanowiły tam także dary, ale dalsze losy tych placówek rzadko można ocenić jako systematyczny rozwój; była to częściej tylko wegetacja ${ }^{16}$.

Biblioteka Stowarzyszenia Subiektów funkcjonowała pomyślnie na pewno dzięki stosunkowo dobrej sytuacji finansowej związku. Ta zaś była wynikiem zwiększającej się stale liczby członków (1890 r. - 567, 1894 r. - 905, 1902 r. 1322) oraz ich specyficznej struktury. Do związku mogli bowiem należeć także czlonkowie-protektorzy, a byli wśród nich np. właściciele najwiekszych firm handlowych w Łodzi czy fabrykanci, którzy niejednokrotnie wspierali Stowarzyszenie finansowo $^{17}$. W znacznym stopniu jednak swój harmonijny rozwój i prawidłową działalność na przestrzeni omawianych 30 lat, biblioteka zawdzięczała autentycznemu zainteresowaniu i zaangażowaniu w jej problemy członków, a zwłaszcza tych, którzy wchodzili w skład Zarządu czy organu nadzorującego pracę książnicy.

Biblioteką opiekował się początkowo wyznaczony spośród członków Zarządu bibliotekarz wraz z pomocnikiem, który wykonywał głównie wszelkie prace techniczne. W połowie lat dziewięćdziesiątych, w miarę powiększania się księgozbioru, powołano do życia komitet biblioteczny. Obok przewodniczącego czyli odpowiedzialnego przed władzami za funkcjonowanie biblioteki, w skład komitetu wchodził sekretarz i kilkunastu (14-16) członków. To właśnie „... dzięki energii i pracy niektórych członków komitetu bibliotecznego zaprowadzono $w$ bibliotece $w$ roku sprawozdawczym pełny porzą$\operatorname{dek}^{n 18}$ odnotowano $w$ jednym $z$ rocznych sprawozdań. Szybki przyrost zbiorów i zwiększająca się liczba czytelników mymagały jednak systematycznej troski i pracy. Zdecydowano więc ustanowić etat płatnego bibliotekarza. „Prawda” w stałej rubryce $W$ dali donosiła już w 1896 r., że Zarząd Stowarzyszenia Subiektów w Łodzi tworzy posadę bibliotekarza z płacą 300 rs. rocznie ${ }^{19}$. W materiałach sprawozdawczych zwiazku potwierdzenie tego faktu znajdujemy dopiero w roku 1902. Obok pensji urzędnika (720 rb) w dziale wydatków jest też pozycja - pensja bibliotekarki - 540 rb rocznie. W 1905 r. bibliotekarka otrzymywała już 675 rb rocznie (inkasent - 825 rb, a

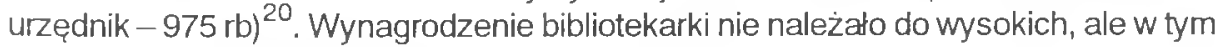
samym czasie (1903 r.) starszy nauczyciel w ródzkiej szkole elementarnej zarabiał 550 $\mathrm{rb}$, a młodszy niespełna $500 \mathrm{rb}^{21}$. Niemal do końca omawianego tu okresu książnica Stowarzyszenia Subiektów była jedyną wśród bibliotek związkowych w Łodzi pozostającą pod stałą opieką fachowego personelu.

Niezależnie od obsady etatowej stale istniał w Stowarzyszeniu organ kolegialny nadzorujący i wspomagający pracę biblioteki. Komitet Biblioteczny, czy później 
Sekcja Biblioteczna, szczególnie obciążony był obowiązkami w czasie I wojny. Księgozbiór, który w początkowym okresie działań wojennych mocno ucierpiał z powodu wzmożonego ruchu czytelników, wymagał uporządkowania i selekcji (wyodrębnienie roczników czasopism rosyjskich). Zebrano także wówczas materiał do nowej edycji drukowanego katalogu zbiorów. Niestety z powodu pogorszenia się warunków ekonomicznych nie udało się zamierzenia tego zrealizować i członkowie Komitetu zmuszeni byli do ręcznego przepisania kilku egzemplarzy. Opracowano natomiast w roku 1916 instrukcję prowadzenia biblioteki. Poza tym Komitet stale czuwal nad doborem księgozbioru, a przede wszystkim nad zapewnieniem funduszy na jego powiększenie. Stałym niemal punktem większości rocznych zebrań sprawozdawczych były wnioski zgłaszane przez członków Komitetu w sprawie powiększenia zaplanowanej w budżecie kwoty na zakup książek. Argumentowano najczęściej, iż liczba dzieł jest zbyt mała w stosunku do ilości czytelników, że brakuje nowości wydawniczych, a w ogóle, że biblioteka jako gromadząca zbiory wielojęzyczne, wymaga znacznie większych nakładów finansowych niż inne księgozbio$\mathrm{ry}^{22}$. Jak duże były faktycznie sumy wydatkowane na bibliotekę i czytelnię (bo planowano te wielkości z reguly oddzielnie) i jaki był ich udział $w$ całości rozchodów Stowarzyszenia przedstawia tabela 1.

Jak wynika z tabeli 1 Stowarzyszenie, niezależnie od otrzymywanych darów książkowych, systematycznie przeznaczało dość znaczne kwoty na powiększenie

Tabela 1. Wydatki na powiększanie zbiorów biblioteki i czytelni

\begin{tabular}{|c|c|c|c|c|c|}
\hline \multirow{2}{*}{ Rok } & Wydatki ogólem & \multicolumn{2}{|c|}{ Wydatki na bibliotekę } & \multicolumn{2}{c|}{ Wydatki na czytelnie } \\
\cline { 2 - 6 } & rb & rb & $\%$ & rb & $\%$ \\
\hline 1888 & 3625,0 & $300,00^{\star}$ & 8,3 & & \\
1890 & 5859,45 & $266,81^{\star}$ & 4,6 & & \\
1892 & - & $300,00^{\text {\# }}$ & & 95,59 & \\
1893 & & 342,82 & - & & \\
1894 & 7800 & 517,93 & 4,4 & 200,00 & 3,9 \\
1895 & 9800 & 702,36 & 7,2 & 118,50 & 1,2 \\
1902 & 16312,45 & 579,07 & 3,5 & 329,70 & 2,0 \\
1904 & 16625,09 & 471,00 & 2,8 & 341,00 & 2,0 \\
1905 & 20027,20 & 653,74 & 3,3 & 303,81 & 1,5 \\
1908 & 12400,89 & - & & - & \\
1913 & 13739,28 & 443,93 & 3,2 & 136,00 & 0,9 \\
1914 & - & 317,38 & & 140,40 & \\
1916 & 15985,46 & 945,20 & 5,9 & 248,08 & 1,6 \\
1917 & 24995,36 & 771,65 & 3,1 & - & \\
\hline
\end{tabular}

* wydatki na bibliotekę i czytelnię liczono wówczas łącznie

* jako wydatki na bibliotekę przyjęto tylko kwoty przeznaczone na zakup ksiażek, oprawę, katalogi, materialy biblioteczne; nie uwzględniono natomiast wydatków na lokal, oświetlenie itp.

Źródlo: Sprawozdania Zarzadu Stowarzyszenia... 
biblioteki i prenumeratę czasopism. Stanowiły one w przypadku biblioteki od 8,3\% do $2,8 \%$ całych wydatków Stowarzyszenia w danym roku. Można przypuszczać, że znacznie mniejsze sumy przeznaczano w latach, dla których nie ma danych, szczególnie w okresie 1906-1912. Stowarzyszenie przeżywało wtedy, podobnie jak inne organizacje, poważny kryzys. Część członków o najbardziej radykalnych przekonaniach odeszla do nowo powstałych związków socjaldemokratycznych i bundowskich. Dokonano przerejestrowania statutu i zmiany nazwy na Stowarzyszenie Wzajemnej Pomocy Pracowników Handlowych ${ }^{23}$.

Ożywienie w działalności biblioteki i czytelni Stowarzyszenia związane jest nie tylko z poprawą sytuacji finansowej związku, ale z przeniesieniem do nowego lokalu, we własnym domu Stowarzyszenia przy ul. Spacerowej 21 (dziś Aleje Kościuszki), co nastappiło jesienią 1912 r. Jak donosiła prasa, obok klubu z bilardem i szachami, obok bufetu, mieściła się tam „... obszerna czytelnia i osobne sale dla biblioteki"24.

Księgozbiór liczył już wtedy ponad 9000 tomów, a biblioteka - zdaniem członków Stowarzyszenia - stanowiła jeden z jego najważniejszych działów i wydatnie przyczyniała się do ożywienia życia towarzyskiego ${ }^{25}$. Pozytywna ocena książnicy (nie tylko przez własnych członków) miała na pewno uzasadnienie w przemyślanej i radkiej, jak na łódzkie warunki, strukturze zbiorów. Tabela 2 obrazuje przyrost zbiorów na przestrzeni 30 lat z uwzględnieniem ich cech językowych.

$Z$ danych zaprezentowanych w tabeli 2 widać, iż biblioteka rozwijała się niezwykle intensywnie w pierwszym piętnastoleciu, co było wynikiem systematycznie realizowanych zakupów, ale także efektem pewnej liczby darów. Sprawozdania z tego okresu wymieniają zwykle kilku lub kilkunastu ofiarodawców ksią̇ek. Komitet Biblioteczny nie przyjął jednak zasady: ilość ważniejsza niż jakość. Sukcesywnie dokonywano więc selekcji w posiadanym zbiorze. Książki niestety także ginęły, a wiele przetrzymywali niesumienni czytelnicy. Wyraźne zmniejszenie liczby zbiorów w okresie wojny wynika nie tyle z ich faktycznego ubytku (chociaż w początkowym okresie działań wojennych wiele książek nie wróciło do boblioteki) lecz z nieuwzględniania - jak dotychczas - w statystyce roczników czasopism oraz usunięcia niektórych periodyków rosyjskich ${ }^{26}$.

Szczególnie interesująca jest natomiast struktura językowa księgozbioru zgromadzonego przez Stowarzyszenie Handlowców. Wielojęzyczność, jaką tu spotykamy, nie była zjawiskiem odosobnionym w ówczesnych łódzkich bibliotekach. Nietypowa jest natomiast objętość poszczególnych grup językowych. Znaczna, bo początkowo ok. 17\%-20\%, liczba książek niemieckich uzasadniona była nie tyle przynależnością do Stowarzyszenia Niemców (chociaż w Łodzi stanowili wtedy ponad $20 \%$ ludności), ile orientacja pewnych grup Żydów na wzorce kultury germańskiej, o czym była już mowa wcześniej. Poza tym należy dodać, że znaczną część oferty handlowej księgarń łódzkich w początkach lat dziewięćdziesiątych stanowiły publikacje niemieckie. $Z$ biegiem lat jednak udział książek niemieckich w zbiorach maleje i nawet w okresie wojny nie przekracza $13 \%$.

Znacznie większy niż niemieckich był natomiast zbiór wydawnictw rosyjskich. Książki rosyjskie musiały obowiązkowo znajdować się w każdej ówczesnej bibliotece, ale nie wszystkie ten obowiązek jednakowo realizowały. W wypożyczalniach 
$-160-$

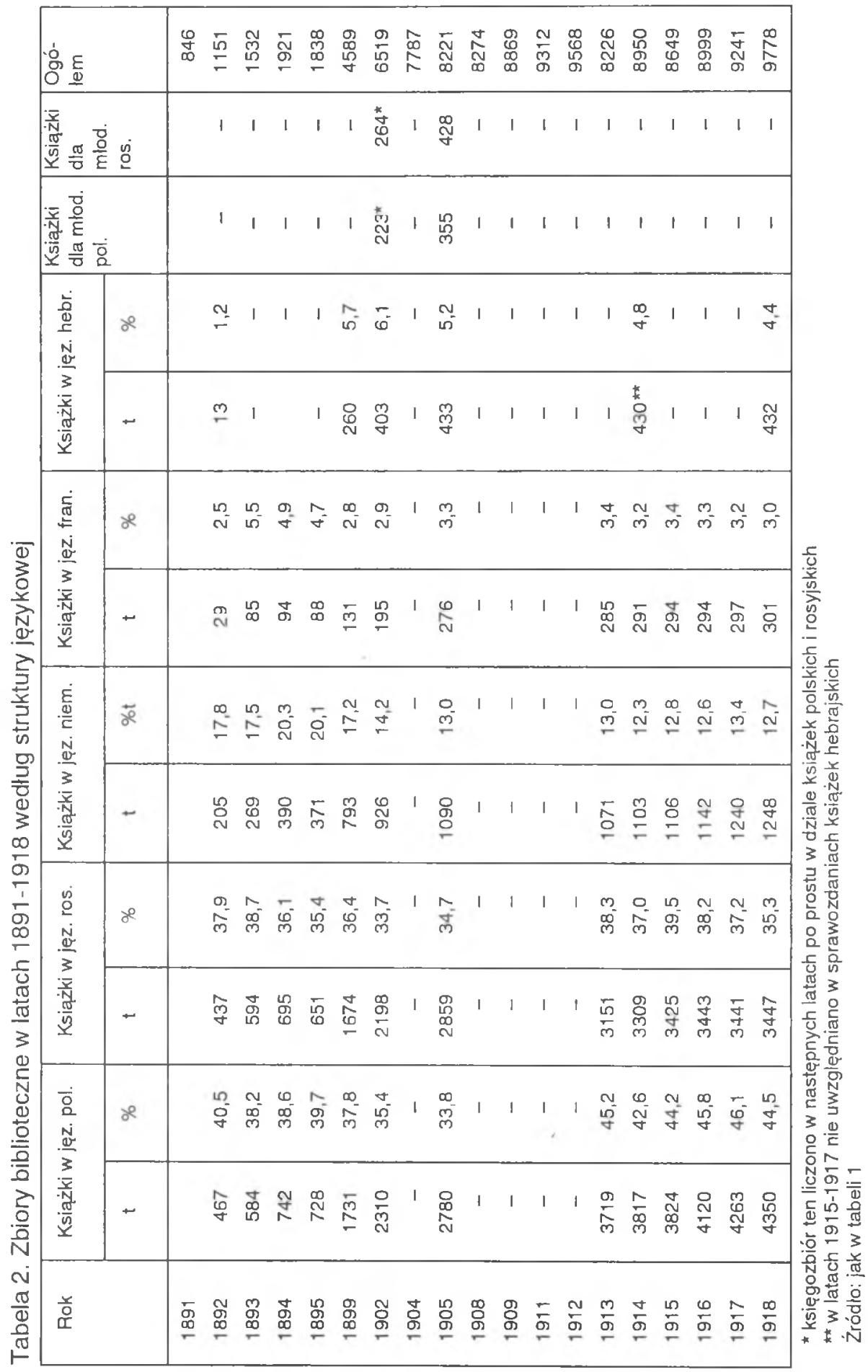


prywatnych np. mimo iż nominalnie gromadziły one wydawnictwa rosyjskie, było ich z reguly niewiele ${ }^{27}$. Biblioteki przy stowarzyszeniach (zwłaszcza założonych przed rokiem 1905) narażone były na ostrzejszą ingerencję władz rosyjskich w politykę gromadzenia zbiorów, ale zjawisko posiadania tak dużej liczby książek rosyjskich zaobserwować można właśnie w związkach zrzeszających środowiska żydowskie ${ }^{28}$. Dowodzi to jednak zauważalnych wśród Żydów tódzkich dążeń rusofilskich.

Książki polskie dopiero w okresie I wojny stanowiły blisko połowę zbiorów (ok. $44 \%-46 \%$ ) i znacznie wtedy przewyższały liczbę rosyjskich.

Uderza natomiast znikoma ilość wydawnictw hebrajskich, pozostająca zresztą przez kilkanaście lat na niezmienionym poziomie i zupełny brak książek w jidysz, czyli jak mówiono $w$ Łodzi w żargonie. Zbiory w tych językach stanowiły często znaczny odsetek $w$ bibliotekach związków zrzeszających glównie Żydów ${ }^{29}$. Wprawdzie w 1912 r. przyjęto wniosek grupy nacjonalistycznie nastawionych Żydów, tzw. litwaków, aby w przypadku jeżeli zażąda tego większość członków, utworzyć bibliotekę żargonową, ale do realizacji tego postulatu nigdy nie doszło ${ }^{30}$.

Członkowie Stowarzyszenia wywierali wpływ na politykę gromadzenia zbiorów nie tylko w kwestii doboru językowego. Niejednokrotnie postulowano na zebraniach nabywanie większej ilości nowości wydawniczych, zwłaszcza z zakresu beletrystyki, czy publikacji o charakterze ekonomiczno-społecznym. Ta ostatnia sugestia pojawiła się w związku z uruchomieniem przez Stowarzyszenie w 1915 r. kursów handlowych ${ }^{31}$.

Jaka była struktura rzeczowa księgozbioru można określić zarówno w kategoriach ilościowych, na podstawie corocznych sprawozdań, jak i w kategoriach jakościowych -w oparciu o opublikowany w 1903 r. katalog zbiorów. Tabela 3 przedstawia proporcje ilościowe poszczególnych grup rzeczowych w latach 1914-1918.

Jak wynika $z$ danych zaprezentowanych $w$ tabeli 3 beletrystyka w okresie wojny stanowiła ok. $50 \%$ zbicrów, a ksiażki naukowe ponad $20 \%$ z tendencją wzrostu. Była to $w$ dziejach biblioteki struktura optymalna, bowiem z fragmentarycznych danych dla lat dziewięćdziesiątych wiadomo, że ksiażek naukowych bylo niewiele ponad $10 \%$, a udziat literatury pięknej w zbiorach dochodzit do $70 \%{ }^{32}$.

W czasie wojny (1916) stosunkowo znaczny był przyrost polskich książek naukowych. Zgodnie z życzeniami członków poszerzono wtedy dział ekonomiczno-społeczny, ale także uzupełniono wieloma nowościami pozostający od dość dawna na niezmienionym poziomie dział polskiej literatury pięknej. W pozostałych działach, z wyjątkiem literatury naukowej niemieckiej, przyrost był minimalny.

Niestety z braku źródeł nie można ocenić jaka była konkretna oferta czytelnicza biblioteki w latach 1914-1918. Znaczną część tej oferty stanowił jednak zbiór posiadany już w roku 1903 i uwidoczniony w wydanym wówczas katalogu. Katalog odbity w tódzkiej drukarni L. Krukowskiego stosowal dwojakie kryteria klasyfikacyjne: językowe i treściowe. Uwidoczniono w nim w oddzielnych układach wydawnictwa w języku rosyjskim, polskim, niemieckim i francuskim (bez hebrajskich). W obrębie dwóch pierwszych grup językowych zastosowano podział na literaturę piękną, książki dla dzieci i młodzieży oraz publikacje naukowe. W poddziałach układ był alfabetyczny. Zbiory niemieckie i francuskie nie podlegają dalszym podziałom ${ }^{33}$. 
Tabela 3. Struktura rzeczowa zbiorów bibliotecznych w latach 1914-1918

\begin{tabular}{|c|c|c|c|c|c|c|c|c|c|c|}
\hline \multirow[t]{2}{*}{ Rok } & \multirow[t]{2}{*}{ Język } & \multicolumn{2}{|c|}{ Beletrystyka } & \multicolumn{2}{|c|}{$\begin{array}{l}\text { Ksiażki nauko- } \\
\text { we }\end{array}$} & \multicolumn{2}{|c|}{$\begin{array}{l}\text { Ksiażki dla } \\
\text { młodz. }\end{array}$} & \multicolumn{2}{|c|}{ Varia } & \multirow{2}{*}{$\begin{array}{c}\text { Ogó- } \\
\text { lem } \\
t\end{array}$} \\
\hline & & $t$ & $\%$ & t & $\%$ & $\mathrm{t}$ & $\%$ & $\mathrm{t}$ & $\% \top$ & \\
\hline \multirow{6}{*}{1914} & pol. & 2369 & & 827 & & 410 & & 211 & & \\
\hline & ros. & 1108 & & 641 & & 478 & & 1082 & & \\
\hline & niem. & 837 & & 171 & & - & & 95 & & \\
\hline & franc. & 272 & & 14 & & - & & 5 & & \\
\hline & hebr. & - & & & & & & 430 & & \\
\hline & Razem & 4586 & 51,2 & 1653 & 18,4 & 888 & 9,9 & 1823 & 20,4 & 8950 \\
\hline \multirow{5}{*}{1915} & pol. & 2372 & & 832 & & 409 & & 211 & & \\
\hline & ros. & 1139 & & 611 & & 480 & & 1195 & & \\
\hline & niem. & 840 & & 171 & & - & & 95 & & \\
\hline & franc. & 275 & & 14 & & - & & 5 & & \\
\hline & Razem & 4626 & 53,5 & 1628 & 18,8 & 889 & 10,3 & 1506 & 17,4 & 8649 \\
\hline \multirow{5}{*}{1916} & pol. & 2463 & & 1015 & & 426 & & 216 & & \\
\hline & ros. & 1148 & & 620 & & 480 & & 1195 & & \\
\hline & niem. & 851 & & 196 & & - & & 95 & & \\
\hline & franc. & 275 & & 14 & & - & & 5 & & \\
\hline & Razem & 4737 & 52,7 & 1845 & 20,5 & 906 & 10,0 & 1511 & 16,8 & 8999 \\
\hline \multirow{5}{*}{1917} & pol. & 2481 & & 1106 & & 455 & & 221 & & \\
\hline & ros. & 1147 & & 620 & & 479 & & 1195 & & \\
\hline & niem. & 857 & & 288 & & - & & 95 & & \\
\hline & franc. & 277 & & 15 & & - & & 5 & & \\
\hline & Razem & 4762 & 51,5 & 2029 & 22,0 & 934 & 10,1 & 1516 & 16,4 & 9241 \\
\hline \multirow{6}{*}{1918} & pol. & 2513 & & 1144 & & 472 & & 221 & & \\
\hline & ros. & 1150 & & 623 & & 479 & & 1195 & & \\
\hline & niem. & 861 & & 292 & & - & & 95 & & \\
\hline & franc. & 281 & & 15 & & - & & 5 & & \\
\hline & hebr. & & & & & & & 432 & & \\
\hline & Razem & 4805 & 49,1 & 2074 & 21,2 & 951 & 9,7 & 1948 & 20,0 & 9778 \\
\hline
\end{tabular}

Źródło: Sprawozdania Zarządu Stowarzyszenia... z lat 1914-1918

W opisie uwzględniono jedynie nazwisko i imię autora (lub tylko inicjał imienia - w przypadku większości książek rosyjskich), tytuł dzieła oraz miejsce i rok 
wydania. Nie zawsze wszystkie te elementy podane są poprawnie, również układ alfabetyczny pozostawia często wiele do życzenia.

Uderza natomiast staranny dobór księgozbioru. W dziale literatury rosyjskiej znajdujemy nazwiska najbardziej znanych ówczesnych pisarzy. Jest więc M. Gorki, N. Gogol, 1. Turgieniew, L. Tołstoj, F. Dostojewski, A. Czechow. Przy każdym nazwisku kilka lub kilkanaście tytułów utworów, głównie wydań z lat dziewięćdziesiątych lub początku XX w. Zawierał jednak dział beletrystyki rosyjskiej więcej tłumaczeń niż utworów oryginalnych. Były to głównie przekłady z literatury francuskiej, angielskiej, ale także z polskiej. Obok znacznej ilości dzieł H. Balzaca, E. Zoli, W. Hugo, G. Sand, K. Dickensa czy Walter-Scota, biblioteka oferowała też przetłumaczone na rosyjski wszystkie niemal utwory Sienkiewicza, kilka powieści Orzeszkowej oraz Emancypantki Prusa. Dział rosyjski znacznie poszerzają ilościowo roczniki wielu czasopism, takich jak „Vestnik Inostrannoj Literatury” czy „Russkaja Mysl”.

Oferta czytelnicza zawarta $w$ dziale literatury polskiej nie odbiega $w$ zasadzie od wzorca z jakim spotkać się można w katalogach zasobniejszych wypożyczalni prywatnych tego okresu ${ }^{34}$. Dominuje bezwzględnie Kraszewski z liczbą 90 tytułów swych utworów. Na drugim miejscu jest Orzeszkowa (50 pozycji), na trzecim Sienkiewicz (34) a dalej Prus i Rodziewiczówna. W księgozbiorze występują licznie powieści z przeszłości Polski takich autorów jak W. Gomulicki, T.T. Jeż czy Z. Kaczkowski obok podejmujących tematykę współczesną jak M. Gawalewicz, W. Kosiakiewicz, W. Marrené. Liczne są również nowości z literatury modernistycznej np. J.A. Kisielewskiego Karykatury i W sieci, L. Staffa Sny o potędze czy Rydla Zaczarowane kolo. Jest sporo utworów Przybyszewskiego, ale brak zupełnie Wyspiańskiego.

Znacznie skromniej była natomiast biblioteka zaopatrzona w dzieła naszych wieszczów. Wśród 8 pozycji Mickiewicza sa wprawdzie 2 egzemplarze Pana Tadeusza, ale brak Dziadów, Grażyny czy Konrada Wallenroda ${ }^{35}$. Podobnie wśród 9 tytułów Słowackiego nie znajdujemy ani Kordiana, ani Fantazego czy Horsztyńskiego. Tak selektywny dobór literatury romantycznej był zapewne wynikiem nadzoru, o którego sprawowaniu, przesyłając zezwolenie na otwarcie biblioteki, przypominał policmajstrowi łódzkiemu gubernator. Podstawowy (choć nieco okrojony) kanon literatury polskiej uzupełniają thumaczenia klasyków europejskich takich jak: A. Dante, W. Szekspir (ale bez Hamleta), E. Rostand, W. Goethe czy A. Dumas. Są też prekłady współczesnych bestselerów europejskich. Tu najwięcej jest utworów E. Zoli, ale są też H. Ibsen czy G. Hauptmann. Czasopism kulturalnych polskich jest niewiele. Katalog odnotowuje jedynie kilka roczników "Atenum” j "Biblioteki Warszawskiej".

Jeżeli chodzi o dział książek naukowych, to należy podkreślić, że nie ma w nim prawie (co zdarzało się często w zbiorach wypożyczalni prywatnych) pozycji o charakterze wybitnie popularnym czy wręcz poradnikowym. Przeważają - jak widać już z zastosowanej klasyfikacji - wydawnictwa z zakresu nauk społecznych, humanistyki. Nie ma zupełnie techniki, a nieliczne publikacje medyczne umieszczono w obrębie nauk przyrodniczych. Na kierunek gromadzenia piśmiennictwa naukowego znikomy wpływ wywierała specyfika organizacji i potrzeby zawodowe jej członków. Piśmiennictwo dotyczące handlu, księgowości, obrotu towarowego 
uwzględniono $w$ minimalnym zakresie. Zauważalny jest natomiast $w$ doborze piśmiennictwa naukowego wpływ ideologii pozytywistycznej, prądów emancypacyjnych i samokształceniowych, czego dowodem choćby posiadanie kompletnego Poradnika dla samouków.

W obrębie każdego z poddziałów starano się zgromadzić podstawowe dla danej dziedziny tytuły. Np. w poddziale Historia literatury, krytyka i sztuka jest większość prac historyczno-literackich P. Chmielowskiego, ale także Brandesa Główne prądy literatury XIX stulecia. W doborze piśmiennictwa naukowego, w niektórych działach, widać wyraźną interwencję cenzury. Oto w bardzo skromniutkim, bo liczącym 28 tytułów, dziale Historia i biografie jest zaledwie kilka pozycji uznanych polskich historyków, obrazujących nasze dzieje (J. Szujski: Historia Polski czy Sz. Askenazy: Dwa stulecia. XVIII i XIX). Są natomiast prace przedstawiające polską przeszłość w ujęciu autorów rosyjskich jak: Puzyrewski: Wojna polsko-russka 1831 czy Kariejew: Upadek Polski.

Tematykę żydowską uwzględniono zarówno przedmiotowo np. Rzut oka na literature żydowską, Przewodnik judaistyczny jak i podmiotowo - prace wielu autorów żydowskich ${ }^{36}$.

Ta pobieżna, z konieczności, analiza zawartości treściowej daje jednak podstawy do wysokiej oceny zasad polityki gromadzenia zbiorów w Stowarzyszeniu Wzajemnej Pomocy Pracowników Handlowych. Byl to na pewno ksieggozbiór znacznie odbiegający od stereotypu ówczesnej biblioteki związkowej (kilkaset przypadkowo dobranych książek) i porównywalny z najlepszymi wypożyczalniami prywatnymi na terenie Łodzi.

Ważnym sprawdzianem trafności przyjętych w bibliotece zasad gromadzenia, jest stopień wykorzystania księgozbioru przez czytelników. Biblioteka Stowarzyszenia Handlowców byla placówką o charakterze zamkniętym, a więc posiadała ściśle określony krąg odbiorców. Stanowili go subiekci, buchalterzy jak i drobni urzędnicy zatrudnieni w łódzkich sklepach i przedsiębiorstwach przemyslowo-handlowych. Byli to ludzie o pewnym poziomie wykształcenia (niejednokrotnie nawet średnim handlowym) lub zdobywający wiedzę w szkołach niedzielnych (np. uczniowie zatrudnieni w sklepach) czy na kursach. Można więc przyjąć, że członkowie tej społeczności mieli wykształcone pewne nawyki i potrzeby o charakterze kulturalno-oświatowym. Jednocześnie trzeba podkreślić, że warunki pracy w handlu na przełomie wieków były niezwykle trudne. Wprawdzie prepisy rosyjskie z $1897 \mathrm{r}$. mówiły o 11,5 godzinnym dniu roboczym pracowników handlowych, ale w praktyce rzadko tego przestrzegano. Subiekci pracowali zwykle kilkanaście godzin, a była to praca niezwykłe wyczerpująca zarówno umysłowo jak i fizycznie. Instytucja wolnych niedziel i urlopów (poza wolnym na 3 święta w roku) praktycznie nie istniała $^{37}$. Do takich warunków pracy musiała się więc dostosować biblioteka, jeśli miała służyć swym użytkownikom.

W pierwszych latach istnienia biblioteka czynna była codziennie od 20,30 do 21,30 , a jedynie w soboty od 15,00 do 16,00 . Wydłużenie $w 1895 \mathrm{r}$. godzin otwarcia do 22,00 , a w soboty od 14,30 do 16,00 spowodowane zostało znacznym wzrostem liczby wypożyczeń (o blisko 50\% więcej niż w 1894 r.) ${ }^{38}$. W okresie zmagań rewolucyjnych 1905-1907, gdy udało się nieco poprawić warunki pracy handlow- 
ców, biblioteka dostosowała się do nowych terminów czasu wolnego (zyskano przerwę obiadowa). Udostępniano więc książki codziennie od 12,00 do 14,00 i od 19,00 do 21,00 . Ten tryb dwukrotnego otwierania w ciągu dnia biblioteki przetrwał do roku 1918. Minimalnej zmianie ulegały tylko godziny wypożyczeńn ${ }^{39}$.

Jako placówka zamknięta, udostępniająca tylko członkom związku, nie pobierała biblioteka początkowo żadnych opłat, co w mieście posiadającym wówczas jedynie kilka prywatnych wypożyczalni było dla potencjalnych użytkowników ogromną szansą. Niestety, wobec zwiększającego się ruchu czytelników, a jednocześnie nasilenia zjawiska nieoddawania wypożyczonych publikacji, Zarząd Stowarzyszenia uchwalił w 1895 r. wprowadzenie jednorazowego zastawu w wysokości 1 rubla od każdego wypożyczonego tomu. Decyzja ta wywołała, rzecz jasna, zrozumiałe niezadowolenie wśród części członków i natychmiastowy spadek czytelnictwa, ale Zarząd utrzymał ją w mocy. Nawet w tej sytuacji wypożyczanie z własnej biblioteki związkowej było znacznie bardziej korzystne niż z wypożyczalni prywatnych, gdzie poza $1 \mathrm{rb}$ zastawu trzeba było płacić miesięczny abonament $w$ wysokości 40-50 kop. od 1 tomu $^{40}$. Wprowadzenie zastawu nie wyeliminowato jednak zupetnie zjawiska przetrzymywania książek ponad wyznaczony regulaminowo termin. Świadzą o tym wymieniane w rocznym sprawozdaniu wcale niemale sumy, jakie biblioteka otrzymywała z tytułu kar za nieterminowy zwrot książek ${ }^{41}$. Można wprawdzie te fakty interpretować i pozytywnie, jako objawy znacznego zainteresowania członków własną biblioteką, najlepiej jednak o wykorzystaniu zbiorów i wyborach czytelniczyć świadczyć będą liczby zaczerpnięte z corocznych sprawozdań Stowarzyszenia. Tabela 4 przedstawia stopień wykorzystania zbiorów z uwzględnieniem poczytności w obrębie poszczególnych języków i dalej według grup treściowych. $Z$ braku źródeł ograniczono się do zaprezentowania zjawiska jedynie w wybranych latach omawianego okresu 1887-1918.

Ilość wypożyczeń mierzona w liczbach bezwzględnych wzrastała niezwykle szybko w końcu lat dziewięćdziesiątych i na początku XX w. Między rokiem 1895 a 1902 nastapił wzrost o prawie $250 \%$. Wiaże się to z podobnym proporcjonalnie wzrostem księgozbioru w tym okresie i znacznym wzrostem liczby członków rzeczywistych Stowarzyszenia - z 719 w 1895 r. do 1044 w 1902 r. Szczytowym, jeśli chodzi o stopień wykorzystania zbiorów, jest rok 1905 (32289 wypożyczeń), po czym następuje gwaltowny spadek udostępnień. Z braku danych za lata 1906-1907 nie wiadomo kiedy konkretnie to nastapiło. Przyczyn takiego stanu rzeczy było wiele. Zasadnicza, to zapewne wspomniane odejście wielu (zwłaszcza młodych) członków ze Stowarzyszenia do nowych związków. W 1905 r. członków rzeczywistych było 1248, a w 1909 r. - 603. Duże zaangażowanie większości członków w wydarzenia polityczne, w walkę o poprawę własnych warunków bytowych, nie sprzyjały rozwijaniu zainteresowań czytelniczych. Także oferta czytelnicza biblioteki pozostawala w tym okresie na prawie niezmienionym poziomie, nowości przybywało bardzo niewiele ${ }^{42}$.

Powrót do poziomu wypożyczeń z r. 1905 nastapił dopiero w połowie wojny, przy czym zupełnie różna była struktura językowa udostępnianych zbiorów. O ile w 1905 r. wydawnictwa w języku polskim stanowiły $47,4 \%$, rosyjskie $-39,7 \%$, a niemieckie $-10,5 \%$ wypożyczeń, to w 1917 r. polskich książek wypożyczono $77 \%$, 
Tabela 4. Struktura wypożyczeń zbiorów bibliotecznych

\begin{tabular}{|c|c|c|c|c|c|c|c|c|c|c|c|c|c|c|}
\hline \multirow[t]{2}{*}{ Rok } & \multirow[t]{2}{*}{ Język } & \multicolumn{2}{|c|}{$\begin{array}{c}\text { Beletrysty- } \\
\mathrm{ka}\end{array}$} & \multicolumn{2}{|c|}{$\begin{array}{c}\text { Książki } \\
\text { naukowe }\end{array}$} & \multicolumn{2}{|c|}{$\begin{array}{c}\text { Gazety i cza- } \\
\text { sopisma }\end{array}$} & \multicolumn{2}{|c|}{$\begin{array}{l}\text { Podręcz- } \\
\text { niki }\end{array}$} & \multicolumn{2}{|c|}{$\begin{array}{c}\text { Ksiażki dla } \\
\text { mlodz. }\end{array}$} & \multicolumn{2}{|c|}{ Varia } & \multirow{2}{*}{$\begin{array}{l}\text { Ogó- } \\
\text { lem } \\
\text { t }\end{array}$} \\
\hline & & $t$ & $\%$ & $t$ & $\%$ & $t$ & $\%$ & $t$ & $\%$ & $t$ & $\%$ & $t$ & $\%$ & \\
\hline 1892 & $\begin{array}{l}\text { pol. } \\
\text { ros. } \\
\text { niem. } \\
\text { franc. } \\
\text { Razem }\end{array}$ & $\begin{array}{r}500 \\
306 \\
289 \\
9 \\
1104\end{array}$ & 88,4 & $\begin{array}{r}15 \\
46 \\
14 \\
- \\
75\end{array}$ & 6,00 & $\begin{array}{r}9 \\
45 \\
9 \\
- \\
63\end{array}$ & 5,0 & $\begin{array}{l}2 \\
1 \\
4 \\
- \\
7\end{array}$ & 0,6 & $\begin{array}{l}- \\
- \\
-\end{array}$ & & - & & 1249 \\
\hline 1894 & \begin{tabular}{l|} 
pol. \\
ros. \\
niem. \\
franc. \\
Razem
\end{tabular} & $\begin{array}{r}2854 \\
1683 \\
1283 \\
194 \\
6014\end{array}$ & $|87,7|$ & $\begin{array}{r}253 \\
136 \\
82 \\
4 \\
475\end{array}$ & 6.9 & $\begin{array}{r}112 \\
182 \\
63 \\
- \\
357\end{array}$ & 5,3 & $\begin{array}{r}5 \\
- \\
5 \\
- \\
10\end{array}$ & 0,1 & $\begin{array}{l}- \\
- \\
- \\
-\end{array}$ & & $\begin{array}{l}- \\
- \\
- \\
-\end{array}$ & & 6856 \\
\hline 1902 & $\begin{array}{l}\text { pol. } \\
\text { ros. } \\
\text { niem. } \\
\text { franc. } \\
\text { hebr. } \\
\text { Razem }\end{array}$ & $\begin{array}{r}13694 \\
7028 \\
3555 \\
754 \\
328 \\
25359\end{array}$ & 79,6 & $\begin{array}{r}441 \\
824 \\
45 \\
- \\
- \\
1310\end{array}$ & 4,1 & $\begin{array}{r}108 \\
760 \\
38 \\
- \\
- \\
906\end{array}$ & 2,9 & $\begin{array}{r}1 \\
4 \\
10 \\
- \\
- \\
15\end{array}$ & 0,05 & $\begin{array}{r}1421 \\
2848 \\
- \\
- \\
- \\
4269\end{array}$ & 13,4 & $\begin{array}{l}- \\
- \\
- \\
- \\
-\end{array}$ & & 31859 \\
\hline 1905 & \begin{tabular}{|l|} 
pol. \\
ros. \\
niem. \\
franc. \\
hebr. \\
Razem
\end{tabular} & $\begin{array}{r}12841 \\
7981 \\
3158 \\
599 \\
178 \\
24757\end{array}$ & 76,7 & $\begin{array}{r}964 \\
1547 \\
213 \\
- \\
- \\
2724\end{array}$ & 8,5 & $\begin{array}{r}25 \\
884 \\
- \\
- \\
- \\
909\end{array}$ & 2,8 & $\begin{array}{r}33 \\
13 \\
21 \\
- \\
- \\
67\end{array}$ & 0,02 & $\begin{array}{r}1427 \\
2405 \\
- \\
- \\
- \\
3832\end{array}$ & 11,9 & $\begin{array}{l}- \\
- \\
- \\
- \\
- \\
-\end{array}$ & & 32289 \\
\hline 1913 & \begin{tabular}{|l|} 
pol. \\
ros. \\
niem. \\
franc. \\
hebr. \\
Razem
\end{tabular} & $\begin{array}{r}13382 \\
5484 \\
1591 \\
445 \\
48 \\
20950\end{array}$ & 89,7 & $\begin{array}{r}220 \\
140 \\
66 \\
- \\
- \\
426\end{array}$ & 1,8 & $\begin{array}{r}13 \\
148 \\
- \\
- \\
- \\
161\end{array}$ & 0,7 & $\begin{array}{r}7 \\
2 \\
12 \\
- \\
- \\
21\end{array}$ & 0,1 & $\begin{array}{r}1112 \\
695 \\
- \\
- \\
- \\
1807\end{array}$ & 7,7 & $\begin{array}{l}- \\
- \\
- \\
- \\
-\end{array}$ & & 23365 \\
\hline 1916 & \begin{tabular}{|l|} 
pol. \\
ros. \\
niem. \\
franc. \\
Razem
\end{tabular} & $\begin{array}{r}18201 \\
3333 \\
4299 \\
797 \\
26630\end{array}$ & 81,1 & $\begin{array}{r}1883 \\
537 \\
252 \\
9 \\
2681\end{array}$ & 8,1 & $\begin{array}{l}- \\
- \\
- \\
- \\
-\end{array}$ & & $\begin{array}{l}- \\
- \\
- \\
-\end{array}$ & & $\begin{array}{r}2886 \\
622 \\
- \\
- \\
3508\end{array}$ & 10,7 & $\begin{array}{r}2 \\
16 \\
18 \\
1 \\
37\end{array}$ & 0,1 & 32856 \\
\hline 1918 & \begin{tabular}{|l|} 
pol. \\
ros. \\
niem. \\
franc. \\
hebr. \\
Razem
\end{tabular} & $\begin{array}{r}25920 \\
2123 \\
2893 \\
641 \\
196 \\
31773\end{array}$ & 79,0 & $\begin{array}{r}497 \\
386 \\
144 \\
2 \\
- \\
4029\end{array}$ & 10,0 & $\begin{array}{l}- \\
- \\
- \\
- \\
- \\
-\end{array}$ & & $\begin{array}{l}- \\
- \\
- \\
- \\
- \\
-\end{array}$ & & $\begin{array}{r}3873 \\
515 \\
- \\
- \\
- \\
4388\end{array}$ & 11,0 & $\begin{array}{l}3 \\
- \\
3 \\
- \\
- \\
6\end{array}$ & 0,01 & 40196 \\
\hline
\end{tabular}

Żródlo: jak w tabeli 1. 
rosyjskich - 10,7\%, a niemieckich - 9,4\%. Spadek zainteresowania piśmiennictwem rosyjskim jest zrozumiały (chociaż ilość wypożyczeń beletrystyki jest jeszcze znaczna), natomiast może dziwić zmniejszenie w stosunku do 1905 r. w mieście Litzmanstadt udostępnień w grupie publikacji niemieckich. Zjawiska te mają związek zarówno z rozwijającym się coraz intensywniej polskim życiem kulturalnooświatowym, jak również świadczą o większej atrakcyjności polskich wartości kulturowych.

Dowodem tego dwukrotnie prawie między rokiem 1913 a 1918 zwiększenie liczby wypożyczeń z polskiej literatury pięknej. Fakt ogromnego zainteresowania beletrystyką oceniano niejednokrotnie krytycznie. Komitet Biblioteczny często ubolewat nad ograniczonym zainteresowaniem wydawnictwami naukowymi, mimo iż kompletowane one były starannie. Wzrost liczby wypożyczeń z działu piśmiennictwa naukowego w okresie wojny, spowodowany był nie tylko uruchomieniem kursów handlowych, ale także nasilaniem się tendencji samokształceniowych w ówczesnym społeczeństwie. Mimo iż znacznie powiększono w 1916 r. dział ekonomiczno-społeczny (podobno na życzenie członków), wię́kszym powodzeniem cieszyły się publikacje o charakterze filozoficzno-filologicznym ${ }^{43}$. Świadczyć by to mogło, iż nie zawsze horyzonty i potrzeby umyslowe handlowców zdeterminowane byly zwykłym utylitaryzmem.

Obok książki i biblioteki ważnym elementem życia kulturalnego a jednocześnie towarzyskiego handlowców była czytelnia. Posiadając około 30 czasopism stała się szybko miejscem chętnie odwiedzanym przez członków, zwłaszcza, że wstęp był bezpłatny ${ }^{44}$. Nie znamy szczegółowej listy abonowanych przez Stowarzyszenie czasopism, ale sądząc po tytułach roczników wymienionych w katalogu i statystyce udostępnień, można przypuszczać, że przeważały bezwzględnie periodyki rosyjskie. Regres czytelniczy, który objawił się po roku 1905 dotknał także czytelnię. Liczba prenumerowanych czasopism zmalała (w $1909 \mathrm{r}$. było ich 20), a i z tych nie wszystkie cieszyły się zainteresowaniem członków ${ }^{45}$.

W sierpniu 1914 r. działalność czytelni uległa zawieszeniu z powodu braku czasopism. Nieliczne, jakie do Łodzi docierały przeniesiono do herbaciarni. Ożywienie życia kulturalno-społecznego, które nastąpiło w roku 1915, zaznaczyło się także w funkcjonowaniu czytelni. W 1916 r. oferowala już 19 czasopism, w 1917 25, a dzienna frekwencja wynosiła średnio 50 osób. Próbowano wprowadzić stałe dyżury członków Sekcji Bibliotecznej, ale stanęły temu na przeszkodzie kłopoty personalne ${ }^{46}$. Wzmożone zainteresowanie czytelnią $w$ tym okresie było zapewne wynikiem zwiększonego zapotrzebowania na bieżącą informację polityczną, spoleczną, ale także na informację i wiedzę fachową. Nie bez znaczenia pozostawał też fakt, że w zimowe miesiące wojenne czynna od 16,00 do 22,00 czytelnia dawała możliwość spędzenia w ciepłym i ogrzanym pomieszczeniu kilku godzin ${ }^{47}$.

Zmianie ulegly wówczas także formy pracy czytelni. Niezależnie od przechowywania roczników niektórych gazet, poczęto kompletować teczki wycinków prasowych. Posegregowane według przyjętego systemu klasyfikacyjnego miały „poslużyć jako materiał orientacyjny w dziedzinie myśli społeczno-politycznej" ${ }^{48}$.

To dostrzeganie nowych potrzeb czytelniczych i właściwe reagowanie na nie jest jeszcze jednym dowodem znaczenia książki i gazety w życiu handlowców. Na 
poparcie tej tezy można jeszcze przytoczyć dowody o charakterze bardziej formalnym. Oto np. w corocznie publikowanych sprawozdaniach z działalności Stowarzyszenia znajdowała się zarówno opisowa jak i liczbowa charakterystyka działalności biblioteki $w$ danym roku. W latach 1914-1918 sprawozdania liczbowe miały już formę znormalizowanej tabelki, w której w celach porównawczych, podawano dla pewnych zjawisk wielkości z roku poprzedniego.

W niektórych poczynaniach Komitetu Bibliotecznego widać cechy działalności określanej dziś terminem informacji zbiorowej, a wówczas w bibliotekach tego typu niezmiernie jeszcze radziej. Było to np. zaznajamianie aktualnych i potencjalnych użytkowników z nowościami nabytymi przez bibliotekę poprzez systematyczne wywieszanie w lokalu Stowarzyszenia wykazów nowych nabytków.

Inną ciekawą akcją było wydrukowanie specjalnych zakładek zawierających zasady prawidłowego obchodzenia się z ksiażką i dołączanie ich do każdego wypożyczanego tomu ${ }^{49}$. To wreszcie $w$ sytuacji panującej $w$ mieście epidemii szkarlatyny, ogłoszono w prasie decyzję o czasowym zamknięciu biblioteki ${ }^{50}$.

Na zakończenie należy wspomnieć o jeszcze jednej bibliotece, której patronowalo również Stowarzyszenie Handlowców. Oto w 1901 r. utworzono przy Stowarzyszeniu czteroklasową Szkołę Handlową i dla jej potrzeb zorganizowano odrębna bibliotekę. Zgodnie z ówczesnymi standardami składała się ona z biblioteki nauczycielskiej, zwanej fundamentalną i uczniowskiej. Obydwie były, jak na warunki łódzkiego szkolnictwa dość zasobne. W 1908 r. biblioteka fundamentalna liczyła 593 dzieła, a uczniowska 647 i nadal byly systematycznie powiększane ${ }^{51}$.

Stowarzyszenie dostrzegało rolę i znaczenie biblioteki nie tylko na własnym, związkowym podwórku. Gdy w maju 1916 r. zawiązało się w Łodzi Towarzystwo Biblioteki Publicznej, Zarząd Stowarzyszenia na zebraniu ogólnym uchwalit rezolucję, w której czytamy m.in. „... w uznaniu wielkiej wagi społecznej, jaką dla ogółu mieszkańców, zwłaszcza zaś dla sfer pracowniczych posiadałaby Biblioteka Publiczna w Łodzi, Ogólne Zebranie... upoważnia Zarząd do wpłacenia... rb 500 jako jednorazowy wpis członkowski Stowarzyszenia... ${ }^{, 52}$. Gest ten potwierdza dodatkowo tezę, iż Stowarzyszenie Wzajemnej Pomocy Pracowników Handlowych było instytucją, która w kształtowaniu kultury książki w Łodzi na przełomie wieków odegrala rolę znaczącą.

Tę wysoką pozycję w łódzkim bibliotekarstwie utrzymywało Stowarzyszenie nadal także po odzyskaniu niepodległości. Należący również i w okresie międzywojennym do znaczniejszych na terenie Łodzi, księgozbiór Związku Zawodowego Handlowców uległ rozproszeniu prawdopodobnie w okresie II wojny światowej ${ }^{53}$.

\section{Przypisy:}

1 Dla potrzeb niniejszego opracowania wykorzystano drukowane Sprawozdania Zarządu Stowarzyszenia Wzajemnej Pomocy Subiektów Handlowych m. Łodzi z lat 1887, 1890, 1892-1895, 1902-1905, 1913-1918 oraz Katalog ksiażek znajdujących się w Bibliotece Stowarzyszenia Wzajemnej Pomocy Pracowników Handlowych m. kodzi, Łódź 1903.

\footnotetext{
${ }^{2}$ Wzmianki o jej istnieniu, dane liczbowe o dzialalności zawarte są w pracy W.L. Karwacki, Związki zawodowe istowarzyszenia pracodawców w Łodzi (do 1914 r.), Łódź 1972 oraz w innych opracowaniach tego autora. Więcej informacji znaleźć można w publikacji J. Konieczna, Biblioteki tódzkie przełomu XIX i XX wieku (1890-1918), Acta Universitatis Lodziensis, Folia Librotum, kódź 1898, s. 200.
} 
${ }^{3}$ Z. Bartkiewicz, Zle miasto, Warszawa 1930, s. 278.

${ }^{4}$ W.L. Karwacki, Związki zawodowe..., s. 27.

${ }^{5}$ s. Wrzosek, Organizacje pracowników handlu, gastronomii i spóldzielczości w Polsce, Warszawa 1972, s. 27-32. Tworzenie stowarzyszeń samopomocowych było w Królestwie Polskim do 1905 r. jedyną właściwie możliwością zrzeszania się na gruncie zawodowym. Możliwość tę wykorzystywali najczęściej najemni pracownicy handlowi.

6 „Dziennik Łódzki” 1888 nr 268, s. 2; nr 270, s. 2-3.

7 Łódź. Dzieje miasta, t. 1 do 1918 r., Łódź 1980, s. 219. Są to dane ze spisu sporządzonego w 1897 r., pierwszego, który można uznać za wiarygodny.

${ }^{8}$ S. Gorski, Łódź spółczesna, Łódź 1904, s. 25-26.

${ }^{9}$ Zezwolenie o nr 15914 nosi datę 4.12.1887. Wojewódzkie Archiwum Państwowe w kodzi (skrót: WAPL), Policmajster m. todzi 452.

10 „Dziennik Łódzki” 1887, nr 284, s. 2.

11 Wypożyczalnie istniały przy następujących księgarniach (w nawiasie daty otwarcia): Juliusza Arndta (1859), R. Schatke (1881), L. Fischera (1882), A. Bedera (1883), H. Strakuna (1887). Z inicjatywy środowiska prawniczego utworzono w 1885 r. wypożyczalnię samodzielną na zasadach spółdzielczych, która jednak z braku poparcia członków, zakończyła żywot w 1888 r. Przy niektórych lódzkich szkołach istniahy też mniejsze lub większe księgozbiory, ale składahy się one glównie z książek rosyjskich dla nauczycieli. J. Konieczna... op. cit., s. 19-24.

12 "Dziennik Łódzki” 1888, nr 114, s. 2. Organizacją biblioteki zajmowal się członek Zarządu Maksymilian Blüht i on przyjmował dary książkowe w kantorze Zakładów l. Poznańskiego. Książki można też było składać $w$ kancelarii Stowarzyszenia. Apele o dary zamieszczane byly równiez w, "Dzienniku kódzkim" 1887, nr 284, s. 2; 1888, nr 111, s. 4.

13 „Dziennik Łódzki” 1888, nr 149, s. 3.

14 Otčet Pravlenija Obščcestva Vzaimnogo Vspomoženija Prikazčikov goroda Lodzi za 1887 god', Łódź 1888.

15 Prasa podkreślała rolę czytelni jako czynnika integrującego środowisko handlowców bez względu na hierarchię stanowisk. Zwracano uwage, że i kobiety-członkowie rodzin zrzeszonych-powinny mieć możliwość korzystania z czytelni. "Dziennik Łódzki” 1888, nr 175, s. 2; nr 232, s. 2.

${ }^{16} \mathrm{~Np}$. biblioteka Stowarzyszenia Wzajemnej Pomocy Nauczycieli Chrześcijan (zał. 1899) liczyła w 1918 r. 1066 tomów, Stowarzyszenia Wzajemnej Pomocy Nauczycieli Żydów (zał. 1898) posiadała w 1918 r. 1378 t. Największa spośród bibliotek związkowych książnica Stowarzyșzenia Komiwojażerów liczyla w 1918 r. 4000 t. zob. J. Konieczna, op. cit., s. 69-70.

17 Z czasem dochodów Stowarzyszeniu dostarczal też wlasny dom, wynajmowany lokatorom. W domu tym mieścił się też Zarząd, biblioteka, Szkoła Handlowa. W.L. Karwacki, op. cit., s. 30.

${ }^{18}$ Otčet Pravlenija... za 1895 god; Lodz 1896.

19 "Prawda" 1896, nr 39, s. 467.

${ }^{20}$ Sprawozdanie Zarządu Stowarzyszenia Wzajemnej Pomocy Pracowników Handlowych m. Łodzi za rok 1902, Łódź 1903; Sprawozdanie Zarządu... za rok 1905, Łódź 1906. Za okres 1896-1901 nie udalo się odnaleźć sprawozdań.

${ }^{21}$ E. Podgórska, Szkolnictwo elementarne w kodzi w latach 1808-1914. Łódź 1966, s. 92-93.

22 Otčet Pravlenija... za 1893 god', Lodz 1894; Sprawozdanie Zarządu Stowarzyszenia Wzajemnej Pomocy Subiektów Handlowych m. Łodzi za rok 1890, Łódź 1891; Sprawozdanie Stowarzyszenia Wzajemnej Pomocy Pracowników Handlowych m. Łodzi zá 1914 r., Łódź 1915; Sprawozdanie Zarządu Stowarzyszenia Wzajemnei Pomocy Pracowników Handlowych m. Łodzi za 1917 r., Łódź 1918; "Dziennik Łódzki" 1892, nr 25, s. 1-2.

${ }^{23}$ W.L. Karwacki... op. cit., s. 101-104. 


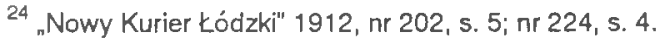

25 "Rozwój” 1910, nr 116, s. 3

26 Sprawozdania z lat 1914, 1916, 1917 i 1918 uwzględniaja już nowy podział zbiorów.

27 Np. w Łódzkiej Wypożyczalni Ksiażek (zał. 1898) wizytujący ją w 1900 r. inspektor drukarń stwierdził, że książki rosyjskie przedstawiają jedynie mieszaninę kilkudziesięciu podręczników i powieści WAPt KGP 1130, k. 127-130.

28 J. Konieczna, op. cit., s. 74-75.

${ }^{29}$ Np. w Stowarzyszeniu Pracowników Handlowych Żydów „Wzajemna Pomoc" stanowiły 32,1\%, a w Klubie Rzemieślniczym im. Jana Kirnrota 27,9\%. J. Konieczna, op. cit., s. 74-75.

30 "Rozwój" 1913 nr 79, s. 3; „Nowy Kurier Łódzki" 1913, nr 79, s. 4.

31 „Kurier Łódzki” 1908, nr 192, s. 3; „Rozwój” 1910, nr 116, s. 3; „Godzina Poiski" 1916, nr 172, s. 6; Sprawozdanie Zarządu... za rok 1916, Łódź 1917.

32 Otčet Pravlenija... za 1894 god', Łódź 1895.

${ }^{33}$ Wobrębie literatury polskiej wyróżniono: Powieści oryginalne i tiomaczone oraz Poezje, komedie i dramaty. Dla publikacji naukowych, tak polskich jak i rosyjskich zastosowano identyczną klasyfikację, są to dzialy: 1. Nauki socjologiczne i polityczne, 2. Filozofia, psychologia, pedagogika i etyka, 3. Historia literatury, krytyka i sztuka. 4. Nauki społeczne i ekonomiczne, 5. Historia i biografie, 6. Podróże, geografia, etnografia, 7. Nauki przyrodnicze i matematyka. Katalog książek znajdujących się w bibliotece Stowarzyszenia Wzajemnej Pomocy Pracowników Handlowych w Łodzi, Łódź 1903, 5. 175.

34 Analize porównawczą katalogów wypożyczalni prywatnych z lat 1864-1892 przeprowadził J. Kostecki, Literatura piękna w księgozbiorach mypożyczalni prywatnych w Królestwie Polskim w latach 1864-1892, „Rocznik Biblioteki Narodowej” 1976/77, t. 12/13, s. 73-97.

${ }^{35}$ Są wprawdzie 2 tomy zatytulowane Poezjei jeden Poematy, ale trudno przypuszczać, aby zawierahy w/w utwory.

${ }^{36}$ Katalog książek...,

${ }^{37}$ S. Wrzosek, Organizacje pracowników... s. 18-23; W.L. Karwacki..., op. cit., s. 236.

${ }^{38}$ Otčet Pravlenija... za 1893 god', Lodz 1894; Otčet Pravlenija... za 1894 god', Lodz 1895.

39 „Kurier Łódzki” 1907, nr 205, s. 3; WAPŁ Mag. m. Łodzi Wydz. Prezydialny 14575; „Nowy Kurier Łódzki" 1913, nr 159, s. 4.

40 Otčet Pravlenija... za 1895 god; Lodz 1896; J. Konieczna... opt. cit., s. 39-41.

${ }^{41}$ Np. w 1902 r. wpływy za przetrzymanie książek wynosiły 115,89 rb, a w końcu 1905 r. 104,90 rb. Sprawozdanie Zarządu... za rok 1902, Łódź 1903; Sprawozdanie Zarządu... za rok 1905, Łódź 1906.

42 „Kurier Łódzki" 1908, nr 192, s. 3.

${ }^{43}$ Sprawozdanie Zarzadu... za rok 1916, Łódź 1917.

44 Sprawozdanie Zar ządu... za rok 1890, Łódź 1891.

45 "Rozwój” 1910, nr 116, s. 3.

46 Sprawozdanie Zarządu... za rok 1914; 1916; 1917.

47 "Nowy Kurier Łódzki" 1916, nr 30, 5. 3.

48 Sprawozdanie Zarządu... za rok 1917, Łódź 1918. Zaznaczyć trzeba, że wśród gazet, których roczniki zdecydowano przechowywać wymieniona jest tylko jedna polska - "Godzina Polski" (mająca opinię tzw. "gadzinówki') i 3 niemieckie: "Berliner Tageblatt", "Leipziger Volkszeitung" i "Vorvärts".

49 "Rozwó;” 1911, nr 222, s. 3; nr 264, s. 6. Oto tekst wydrukowany na zakladce: „Do czytelników. Proszę nie rzucaj mnie na stół z kartą otwartą, nie rób na mnie uwag ołówkiem lub piórem, nie gaś mną świecy, raczej dmuchnij w płomień, nie zaginaj karty, lecz włóż zakładkę, nie czytaj mnie podczas 
jedzenia, gdyż mnie poplamisz. Słowem szanuj mnie, chcę bowiem pozostać czystą, świeżą i służyć innym. Książa".

50 „Kurier tódzki” 1906, nr 168, s. 2.

51 "Kurier Łódzki" 1909, nr 99, s. 4-5; 1910, nr 22, s. 4.

52 Sprawozdanie Zarządu... za rok 1916, tódź 1917.

${ }^{53}$ Po 1918 r. Stowarzyszenie przeksztalcilo się w Związek Zawodowy Pracowników Handlowych i Biurowych m. Łodzi. E. Chwalewik: Zbiory polskie. Archiwa. Biblioteki. Gabinety t. 1, Warszawa 1926 notuje, iż biblioteka w/w Związku „liczy przeszło 12 tys. t. różnej treści i w różnych językach". W 1931 r. Związek przyłączył się jako Oddział lódzki do Powszechnego Związku Zawodowego Pracowników Handlowych i Biurowych w Polsce. L. Hass: Organizacje zawodowe w Polsce 1918-1939 (Informator), Warszawa 1963 , s. 548, 553. Ze Sprawozdania "nowego" Związku za rok 1937/38 wynika, iż nie posiada on żadnej biblioteki. Prawdopodobnie księgozbiór zostal przekazany na rzecz innej biblioteki czy instytucji. Związek Pracowników Handlowych był już wtedy organizacją podejmującą wylącznie problematykę interesów pracowniczych, a zrzeszat tylko Zydów. Ustalenie dalszych losów biblioteki jest niemożliwe, ponieważ ani Biblioteka Miejska, ani Biblioteka Uniwersytecka w Łodzi nie prowadzą kartotek proweniencji swych zbiorów. 